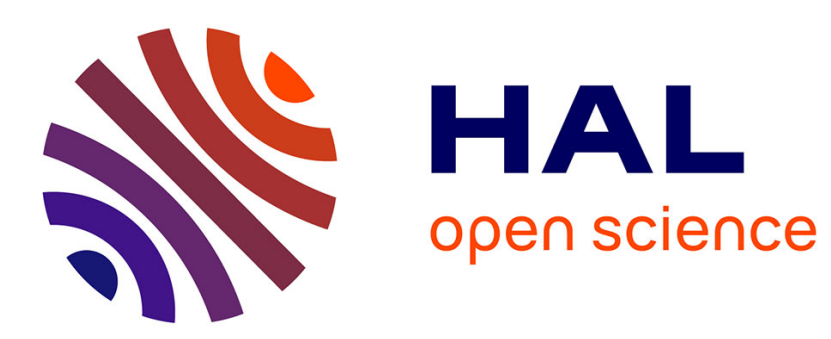

\title{
Nationalities and universalism in the early historiography of photography (1843-1857)"
}

François Brunet

\section{To cite this version:}

François Brunet. Nationalities and universalism in the early historiography of photography (1843-1857)". History of Photography, 2011, History of Photography, 35 (2011) (2), 98-110 / http://dx.doi.org/10.1080/03087298.2010.516587. hal-01378184

\section{HAL Id: hal-01378184 \\ https://hal-univ-paris.archives-ouvertes.fr/hal-01378184}

Submitted on 9 Oct 2016

HAL is a multi-disciplinary open access archive for the deposit and dissemination of scientific research documents, whether they are published or not. The documents may come from teaching and research institutions in France or abroad, or from public or private research centers.
L'archive ouverte pluridisciplinaire HAL, est destinée au dépôt et à la diffusion de documents scientifiques de niveau recherche, publiés ou non, émanant des établissements d'enseignement et de recherche français ou étrangers, des laboratoires publics ou privés. 
Nationalities and universalism in the early historiography of photography $(1843-1857)^{i}$

François Brunet (Université Paris Diderot, Laboratoire de recherches sur les cultures anglophones)

Few historians or critics in 2010 would accept the once popular view of photography as a "universal language", one that, as Helmut Gernsheim put it, is "understood in all parts of the world" and links "the family of man"ii. If we tend now to distrust this view, however, it is not primarily because we think of photography as a collection of national idioms - even allowing for the great recent output of national surveys. Rather, we have grown suspicious of the twin ideas of universality and transparency, which we regard as situated macro-culturally and historically. On the one hand, the optical and archival aspirations underlying the invention of photography are seen today as rooted not in some universal, ahistorical "dream of mankind", but in a distinctly Western European cultural history. On the other, the spread of photography around the world has often been described as auxiliary to the globalizing political economy of capitalism and colonialism. Thus the kind of oppositions that matter most in the contemporary critique of visual culture are supra-national (North / South, West / East), as well as infra-national and societal (race, class, gender), rather than (inter) national. To a certain extent, even, surveys of the photohistories of Brazil, Japan, China, Egypt, or Scotland, have been construed as works of resistance or diversification against the historiographical weight of photography's "superpowers", France, England, the United States, the German-language area, and the kind of Eurocentric history these giants tend to perpetuate ${ }^{\mathrm{iii}}$. If we add that this "established" Eurocentric history has invested a great deal of effort in pacifying the once inescapable paternity quarrels surrounding the invention of photography - first and foremost the Franco-British feud-, we may begin to explain why the subject of photographic nationalities, particularly among the medium's early giants, has become something of a blind spot in historical studies ${ }^{\text {iv }}$. Needless to say, the limited scope of this paper will not permit anything like a full treatment of a potentially immense subject. What I propose here is merely to suggest the relevance of nationalities in early photographic literature (or historiography), by offering a survey of a series of texts, mostly British and French, from photography's first two decades. I will concentrate on an ambivalence, in this period, between two polarities: on the one hand, expressions of nationalism and more broadly of national categories in both the practice and the judgement of photography, and on the other, an aspiration for the universality of "sun painting", or at least for photography as an international social or cultural value. This ambivalence may in part reflect a divide between professional authors and more intellectual critics, which I will not study in detail. I will instead emphasize the context of the first international exhibitions of photographs, which, like the larger World Fairs of the period, displayed the contest of nations as the visible form of civilization's progress.

As is known, the contradiction between photography's universal and national polarities first emerged in the Franco-English publication procedures of 1839, and more generally in the Franco-English debate on photography or the idea of photography. This debate not only produced the technological duality of daguerreotype and calotype and its multiple legal, institutional, technological, commercial consequences. It also engendered, in my view, a broad conceptual alternative, a dialectics defining photography between representation and expression, between an art of the object (more closely associated with Arago's speech at the French Parliament) and an art of the subject (particularly explored by Talbot in the Pencil of Nature), or, in other terms, between a kind of institutional apparatus of visual truth, legitimized as a visual expression of democracy, and a kind of libertarian medium of visual creation, associated by Talbot and the 
calotype school with more aristocratic values ${ }^{\mathrm{v}}$. More directly relevant to this paper is the tension that existed within the French publication process itself - specifically in Arago's discourse and actions - between the universal(ist) and national(ist) polarities. There is the contradiction between the celebrated French "gift to the world" of photography, in the free publication of the daguerreotype process, and the infamous patent taken out in England by Daguerre's agent Miles Berry. But a more fundamental contradiction opposed Arago's 1839 framing of photography as a natural, a-technical mode of picture-making, answering an "old dream of mankind", open to everyone and universally understandable and utilizable, and his continuous insistence on establishing the history of this epochal invention and its later progress as "French throughout", Arago's fervent patriotism, or spirit of "nationality", as Talbot once put it, was rooted in his Rationalist, Revolutionary and Napoleonic heritage, which viewed France as the birthplace and protector of universalism, particularly in opposition to England or at least to the English conservative tradition $^{\text {vii }}$. This explains, for instance, why the first application of photography Arago presented to the French Parliament was the imaginary recreation of Napoleon's Egyptian campaign and the utopian program of photographing "millions of hieroglyphs", thus offering a prestigious master corpus for photography as a natural and universal language ${ }^{\text {viii }}$ but also as a symbolic terrain for the clash of French and British imperial enterprises, in Egypt and elsewhere.

One important British reverberation of this early oscillation between universalism and patriotism is to be found in the article published in 1843 in the Edinburgh Review, usually attributed to David Brewster ${ }^{\text {ix }}$ (Fig. 1). The core of this seminal essay consisted jn a remarkably balanced recapitulation of the European history of photochemistry, with especial insistence on the parallel rise of the French (Daguerreian) and English (calotype) processes. Brewster was arguably the first general commentator to point out the inconsistency of the English patent with the "liberality with which [France] has purchased [the process] for the benefit of universal science", an "omission", Brewster emphasized, "which we would almost venture M. Arago still to supply"x. Declining to claim for Talbot "any priority in reference to Daguerre" or to make "the least deduction from the merits of M. Daguerre", Brewster nonetheless clearly identified the superior merits of the paper process (especially its lower cost, "portability, permanence, and facilty of examination", above all its "power of multiplication"xi ), and went on to detail some important improvements on the calotype process, particularly by the American John Draper and the German Ludwig Moser. It is in the light of this very international narrative that we must read Brewster's emphatic peroration, where he pitted France's "generous heart and open hand" in offering her "gift to all nations" against the inability of England either to prevent the patenting of the daguerreotype ("In England alone, the land of free-trade - the enemy of monopoly - has the gift of her neighbour been received with contumely and dishonour") or to ensure a "national reward" for the inventor of the calotype. The impact of nationality (construed, here, as a framework for public policy) for the young history of photography could hardly be expressed more vigorously. Yet as if to drive the point even further, the last sentences of the paper established an unmistakeable connection between "national" protection (or lack thereof, as in England) of the new art and the prospect of its application to programs of national or imperial illustration:

Nor does the fate of the Calotype [in England] redeem the treatment of her sister art. The Royal Society - the philosophical organ of the nation-has refused to publish its processes in their Transactions. No Arago - no Gay-Lussac, drew it to the notice of the Premier or his Government. No representatives of the People or the Peers unanimously recommended a national reward. No 
enterprising artists started for our colonies to portray their scenery, or repaired to our insular rocks and glens to delineate their beauty and their grandeur. $[\ldots]^{\mathrm{xii}}$

As already suggested by these words, several broad trends favoured, in the 1850 s, the extension of national and nationalist concerns from the realm of invention to the plane of photographic practices and images. The swift transition, in Europe, from the daguerreotype to negative-positive photography, though accompanied by renewed discussions of priority and property, accelerated the transformation of photography from the status of invention and its primary usage as a commercial medium of portraiture to its modern status as a social and public form of visual culture, evidenced at the end of the $1850 \mathrm{~s}$ by stereography and its attendant industries, photo-illustrated albums, and the carte-de-visite boom. This transition was accompanied by the emergence of specific, national or regional, photographic institutions and periodicals, and, in close parallel, the regular display of photographs at large-scale international exhibitions. Finally, the original group of the founding photographic nations, all European, was augmented around 1850 by the rather sudden introduction of American photographic equipments and pictures on the European scene. Thus it was in the triple context of emerging national associations, recurring international exhibitions, and aggressive American efforts to reach European markets and arenas, that the competing claims of nationality and universality were recurrently staked for photography as a pictorial and cultural medium.

In the wake of the publication of Frederick Scott Archer's collodion process, national photographic associations and periodicals promoted nationalist discourses on matters of technology and trade. In the U.S., the creation of the first photographic societies and periodicals was fuelled by various controversies involving claims on "American" processes and patent discussions, the clearest example being the affair of the "hillotype", an incomplete colour daguerreotype process that between late 1850 and 1853 seemed to promise an American revolution in photography ${ }^{\text {xiii }}$. In France and Britain, the formation of national photographic societies was in part a race for international leadership. Charles Eastlake, in preliminary efforts towards forming the London Photographic Society, appealed to Talbot in 1852 to relax his patents, arguing that "the art of photography upon paper, of which you are the inventor, has arrived at such a degree of perfection that it must soon become of national importance ... at present, however, although England continues to take the lead in some branches of the art, yet in others the French are unquestionably making more rapid progress than we are. It is very desirable that we should not be left behind by the nations of the continent in the improvement and development of a purely British invention"xiv . Between 1852 and 1855 photographic relations between Paris and London, though somewhat pacified, were still marked by deep antagonisms. The short-lived French periodical La Lumière consistently occulted Scott Archer's glass process in favor of Le Gray's wax paper process. As André Gunthert has shown, its early demise, along with that of the ephemeral Société Héliographique, was largely determined by its Anglophobia and impudence ${ }^{\mathrm{xv}}$.

Conversely, international exhibitions-foremost the London Great Exhibition of 1851 and the Paris Exposition of 1855 (Fig. 2) - highlighted rankings of national achievements in technology and art, tending to explain such hierarchies by various discursive strategies that commonly relied on the $18^{\text {th }}$-century framework of civilization and progress as a peaceful competition of national energies and characters ${ }^{\mathrm{xvi}}$. The Crystal Palace Exhibition, whose larger agenda included an effort towards establishing international industrial standards, put in relief not only the technological diversity of photography but a paradoxical distribution of photographic nationalities, often rehearsed by $20^{\text {th }}$-century historians: in the daguerreotype department the pre- 
eminence was accorded to American exhibitors, who carried three first-class medals, while the French led in the English process of the calotype and England excelled in the glass process, considered then partly French in origin. In the jurys' general report on the photographic collection, it was stated that:

for daguerreotype portraits, America stands prominently forward;--France, first in order of merit for calotypes, or sun-pictures; - England, possessing a distinct character of her own, and presenting illustrations of nearly all the processes which have as yet been adopted. America stands alone for stern development of character; her works, with few exceptions, reject all accessories, present a faithful transcript of the subject, and yield to none in excellence of execution. France, in her daguerreotypes, of which she has but few, offers bright sunny representations; their effect rather injured than improved by too great masses of sunlight; but in her calotypes she stands unrivalled, and but rejecting the processes of Daguerre, has concentrated all her energies in the further development of those of Talbot and his school ${ }^{\text {xvii }}$.

This seemingly surprising distribution of roles could easily have been explained by legal, technical, and commercial factors - notably Daguerre's and Talbot's patents in England, French disrespect for the latter, intense American ingenuity and competition-but in 1851 it became the object of comparative discourses on national geniuses, characters and traditions. One influential trope of such discourses was a naturalistic theory of photographic climates, which clung to the notion of photography as sun painting, and which Arago had first vented when he had claimed, back in 1839, that a bright Southern sun would produce stronger actinic power. Thus in 1851 climate was invoked to explain the somewhat disturbing success of American daguerreotypists. The Crystal Palace jury suggested, in a spirit of "fairness" to English "photographists", that the striking results of American daguerreotypes, whatever their technical merits, had been "seconded by all that climate and the purest of atmospheres could effect", and that attention was due to "the importance of a clear atmosphere" in order not to "overrate the superiority of execution which America certainly manifests"xviii. Although the critics of the Illustrated London News and the Athenaeum ostensibly differed from such official explanations ${ }^{\mathrm{xix}}$, a debate on visual nationalities had clearly begun, and within this debate the climate thesis enjoyed a measure of success, especially in the US. In an era of virulent American expansionism and cultural nationalism, summed up by the cry of "Manifest Destiny", popular patriots such as Horace Greeley were quick to exploit the "triumph" of American daguerreotypists, and slogans such as "an American sun shines brighter" gained credence, American photography henceforth presenting itself as the home of a practical, democratic kind of realism ${ }^{\mathrm{xx}}$.

Meanwhile in France, in the context of the newly established Second Empire and its ambitious photographic projects, a great amount of attention was paid, as André Rouillé has shown, to the expansion, industrialization and vulgarization of photography, still largely conceived as a purely French invention, and now largely envisioned as an auxiliary of French imperial prospects by professional authors who generally ignored or despised foreign pictorial contributions $^{\mathrm{xxi}}$. Witness, for example, this passage from Ernest Lacan's Esquisses photographiques, a book-long commentary on the 1855 photographic exhibition attached to the Paris Exposition:

[It is since 1851 that] photography [...] has become such a powerful auxiliary for sciences and arts. It has, by and by, come down from the rooftop of the portrait maker to the painter's studio, the scientist's laboratory, the man of the world's cabinet, even to the boudoir de nos élégantes. It has crossed the seas, passed mountains, traversed continents: there are photographers in Bombay, 
Madagascar, Valparaiso; and, as one applies it to one's tastes or needs, it has gone, with the artist and the tourist, into museums, cathedrals, the darks of silent woods, the rugged tops of the Alps or the Pyrénées ... xxii

It is, nonetheless, in the official report of the (international, but predominantly French) jury for this exhibition that we find one of the clearest statements about the distinctive merits of French and English photographs — indeed French and English photographies — which together towered above all other nations in the final medal count. Specifically, this jury formulated a cultural theory of photographic nationalities, by remarking on a rather predictable division of labour between English landscapes and French monuments. In their overview of the photographic exhibitions, the jurors justified the greater count of medals awarded to France by a claimed deficit of English monuments :

Between the two nations, the first rank may be attributed to France, for while to the admirable English views and landscapes of Messrs. Fenton, Maxwell Lyte, Llewelyn, France can oppose in perfection those of Messrs. Martens, Aguado, Heilmann, Great Britain has nothing to match the gigantic reproductions of monuments by Messrs. Baldus and Bisson, or the curious heliographic plates of Messrs. Niepce de Saint-Victor, Nègre, Baldus and Biffaut. Bavaria exhibited portraits which, with respect to modelling and effect, several persons place above every other comparable product $^{\text {xxiii }}$.

Further on the near absence of monuments in the English exhibition was pointed out, even though England, the jury mused, "contains magnificent cathedrals well worth the attention of photographers", and though "no people travel as much as the English and could have, as they, make us know the monuments of the whole world"xxiv . In the landscape section, however, the jurors unequivocally admitted English superiority, echoing in this connection the traditional painterly distinction between colour and line:

While the English school does not display prints on so colossal a size as those of Messrs. Legray, Baldus, and Bisson, through the use of collodion it attains effects of transparency, perspective and light that are so particular as to warrant the appellation of colourist. Collodion, as used by the English photographers, has some special qualities that must be attributed to the presence of a great proportion of potassium bromide, which is more easily impressed than iodide by green rays. Thus it is that foliage is more nuanced [on English photographs], especially in the shadows, and never displays those black masses that impair some of the best productions of French photographers.

And here is how they justified the first-class medal awarded to Roger Fenton and his "many landscapes", which they characterized as a whole by perfection and variety (Fig. 3-4):

In the Valley of the Warfe and in Huck Fall, the tints are gradated with such truth that one could tell the distance between each ground in the terrain; ordinarily in photographic landscapes the various grounds appear packed one against the other, as in painted stage sceneries, and one cannot feel the air moving between them. It is impossible to render perspective better than in the Pool before the Strid, which represents two fishermen on rocks in the middle of a forest crossed by a stream. Several views of Rivaulx Abbey, as well as instantaneous prints of Admiral Napier's English fleet, leaving Portsmouth, demonstrate the variety of Mr. Fenton's talents, and the profit he has availed himself in using the collodion process ${ }^{\mathrm{xxv}}$. 
Such judgements, as those mentioned above in the context of the Crystal Palace Exhibition, typically marginalized what I would call historical factors (such as, in France, the political agenda behind the photographic inventory of historical monuments and the institutional reasons for prolonged indifference to the collodion process), covering them with "cultural" and even archetypal wisdoms that bordered on cliché. The proposed distribution of roles between English landscapes and French monuments, while sanctioning the marginalization of portrait (and thereby American) photography ${ }^{\mathrm{xxvi}}$, clearly disregarded Fenton's views of ruins and abbeys, among others (Fig. 5) ${ }^{\mathrm{xxvii}}$. Yet it served an obvious diplomatic role: justifying the overall pre-eminence of the French, while recognizing merit to the English, and rehearsing well-established arthistorical distinctions and hierarchies (particularly between landscape and history as genres). This particular theory was to enjoy considerable success in the later historiography, down to a 1985 article by Israeli scholar Yeshayahu Nir, for whom a comparative survey of $19^{\text {th }}$-century European photography in the Holy Land demonstrated precisely this same partition of tastesmonuments and inscriptions for the French, landscapes and atmospheres for the English-, thereby suggesting the play of "cultural predispositions" and even religious heritages in the early artistic progress of photography ${ }^{\text {xxviii }}$. Whatever its actual merit for art history, this theory of cultural climates could, in France in the 1850s, be twisted to serve clearly ideological and even xenophobic goals, as another, lesser known document will show.

Though very obscure today, the French writer Théophile Gautier's account of the 1857 exhibition of the Société Française de Photographie contains a striking discussion of the relationship between universality and nationality in photography-especially as it is articulated to a precociously modern reflection on photography as art ${ }^{x x i x}$. Along with Flaubert, Gautier belonged to the Realist offshoot of French Romanticism, and as such was called a "photographic" writer by champions of the "ideal". In France this classic debate came to a head some time before Baudelaire famous 1859 diatribe on photography, precisely in 1857, with the manifesto on Realism by the critic Champfleury, which staged a parable pitting ten daguerreotypists and ten painters in an open field, and concluded that the ten mechanical images turned out identical, whereas among the ten paintings "not one was like another"xxx. Gautier's text would seem to have been composed precisely to counter this anti-photographic argument, and by the same token to vindicate his own brand of Realism. For the writer, photography was no mere chemical operation, but involved significant human choices and, in a word, taste. Strikingly, it was nationality that served as evidence of the great truth that the "soul of man" always shows through whatever he touches. "In an exhibition of heliographic prints from various countries, Gautier wrote, nationalities are easily recognized". Hence followed a gallery of national styles, typically starting with English photography, and typically describing it as purely derivative:

English photography, for example, resembles paintings and engravings from Britain; it has the look of keepsake and book of beauties, nature in it is made to look like something clean, neat, shiny, smooth, elegant, and fashionable [italicized terms in English] that catches the least attentive eyes. You see some animals and you think they are done after Landseer; landscapes remind you of Constable, Turner, Callow, and William Wyld; daily scenes are Mulreadys and portraits are Lawrences. You will object that such a character owes to the land itself, or the nature of the objects represented, and that there is nothing so surprising about the reproduction of an English site or person wearing an English cachet; yet the same physiognomy remains, even when the picture is made in Egypt or in Greece, after very different types. Albion's photographers have a manner of placing their models, of distributing their lights, of taking their points of view, that cannot be mistaken. Some are more Byronian, some are Lakists in the way of Wordsworth, some are Biblical in the Martynn genre, some are Neo-raphaelites like Millais. 
The French writer did not find other photographic nationalities worthy of such eulogium:

Germans, on the contrary, produce a kind of photography that is intimate and homely, as in a novel by Auguste Lafontaine; they display maudlin sentimentality, Swabian naivety, a housekeeper's care and punctilious cleanliness; they place soulful figures in interiors that are crowded with home utensils; wherein Charlotte, who was just leaning out of the window amid the volubilis, exclaiming "o Klopstock!" while gazing at the moon, turns back to cut out slices of bread and butter for the little children. [Germans] lack colour, and their pictures generally display the soft pallor of those charcoal card drawings that the painters of Munich, Berlin or Düsseldorf never seem to manage to colour on the wall.

As for Belgians, they "have no clearly marked character; they imitate the French and can only be distinguished by a slight Walloon accent." "With the Italians, Gautier went on, we recognize the taste for monuments, the love of the grand style of painting, the passion for archaeology; they care for art more than they do for nature, and seek the beauty of lines before the magic of effect. Like their painters, they lack chiaroscuro; broad light, strong locality, clear-cut shadow are the ordinary qualities of their photographs." After such a definitive gallery of foreign national types one is curious to hear what Gautier had to say about the French-and one is perhaps not surprised to find that they defied such convenient typology:

Individuality reigns among the French: everyone follows his particular idea; the same diversity of genres is found at the photographic exhibition as at the Salon-strange thing to say, and yet true, one finds among the French photographers the draughtsmen and the colourists; the former fix their contours, cut out sharp outlines, and admit but white or grey tints; whereas the latter blur the edges of objects, concentrate their lights, thicken their shadows, warm up their tones, silk up their blacks, and even know how to darken up [culotter] the sun's work as an old Rembrandt etching is softened down [estompée] on yellow paper. Each photographer of repute has his cachet, and his prints do not need his signature to be unravelled from those of others. This [diversity] owes to lenses, chemical agents, albumen, collodion, washing, wax paper or glass plate, to the weather on that particular day, the length of exposure in minutes or seconds, the colour, nature, greater or smaller immobility of the model - something, no doubt, to each and every one of these circumstances, but chiefly to the artist's taste, his manner of considering and understanding things, of choosing, arranging, disposing, and above all — why not say it? — to a certain fluidic transmission, which science is not capable of ascertaining today, but which exists nonetheless.

Thus Gautier came back to his main thesis - that there was a significant "action of the photographer on the photograph", an action "great enough to give a different style to the apparently mathematical reproduction of a like object"-a theme that resonated with the French critical debate of the late 1850 s and tended to disprove Champfleury's experiment. Thus nationality came into play as the preferred illustration of the artfulness of photography. In this sense Gautier's theory could be called a theory of artistic climates. Moreover, Gautier defined the French national style as individuality - i.e. as the lack of a national style, thus equating Art with France and, in a sense, condemning other nations to merely photographic photography. Whereas English or German photographs seemed mere photographs, we might say, of national artistic traditions and types, it fell to the French photographers to embody true photographic creativity and therefore to confirm at once the art of photography and the genius of France. 
Such photographic patriotism, whether natural, cultural or artistic, is remarkably lacking from the last text I want to review, Lady Elizabeth Eastlake's famous 1857 essay on photography, to which I turn, indeed, as the period's prime statement of photographic universalism. Wife of Charles Eastlake, who had been the president of the Royal Academy (1850) and the first president of the London Photographic Society (1853), but probably a more active and enthusiastic fan of photography than her husband, especially through her Scottish connections, Lady Eastlake was especially known as a conservative but astute art critic and a brilliant travel writer, versed in several languages and continually touring the Continent (Fig. 6). In her Quarterly Review articles she not infrequently commented on national characters and traditions, and in 1845 she published a striking essay on "Lady Travellers", which linked the feminine "domestic" orientation - particularly characteristic, in her view, of English women-with a greater ability to discover and appreciate foreign cultures ${ }^{\mathrm{xxx}}$. Her 1857 essay on photography, truly a founding text for the cultural and artistic critique of the medium, is striking as a kind of conclusion to - and perhaps a discreet critique of - the debate on photographic nationalities in the 1850 s.

The essay opened with a social utopia, a liberal vision of the expansion of photography as social progress. Photography, for Eastlake, was "a new sympathy", uniting "men of the most diverse lives, habits, and stations, so that whoever enters its ranks finds himself in a kind of republic, where it needs apparently but to be a photographer to be a brother"xxxii . This "republic" united society - at least English society ("the nobleman, the tradesman, the prince of blood royal, the innkeeper, the artist, the manservant", etc.). In the same vision, the formation of photographic societies united the United Kingdom - excepting Scotland (where the Photographic Society of Edinburgh was just forming): "Liverpool assists Norwich, Norwich congratulates Dublin, Dublin fraternises with the Birmingham and Midland Institute, London sympathises with each, and all are looking with impatience to Manchester." Photography also united Britain and British India, it united Britain and France, indeed it united all of Europe:

Nor is the feeling of fellowship confined to our own race. The photographic and political alliance with France and this country was concluded at about the same period, and we can wish nothing more than that they may be maintained with equal cordiality. The Duke de Luynes, a French nobleman of high scientific repute, has placed the sum of 10,000 francs at the disposal of the Paris Photographic Society, to be divided into two prizes for objects connected with the advance of the art,--the prizes open to the whole world. The best landscape photographs at the Exposition des Beaux Arts were English, the best architectural specimens in the London Exhibition are French. The Exhibition at Brussels last October was more cosmopolitan than Belgian. The Emperors of Russia and Austria, adopting the old way for paying new debts, are bestowing snuff-boxes on photographic merit.

Registering the wave of international events and contests that set in after 1851, such as the Paris Exposition of 1855, the 1856 Brussels Exposition "for the encouragement and development of industrial arts in Belgium", which was repeated in 1857, etc., and the famous "concours du duc de Luynes", launched in 1856 by the French Photographic Society in order to stimulate the elaboration of "permanent" photographic prints and practicable photomechanical methods, Eastlake consistently chose to describe these events in internationalist, or at least highly diplomatic, language. While the "political alliance" with France reflects the revival of the Entente cordiale in the first years of the Second Empire, the notion of a contemporary "photographic alliance", in the 1850s, remains quite debatable, as we have seen. As for the competition 
sponsored by the Duke of Luynes, it was indeed declared open to all nations, the object being, as the French society's Bulletin noted, "art in the general point of view, and not from the point of view of national work"xxxiii. However, although several English competitors were registered, it would seem that their merits may not have been properly regarded; in the end, both the small and great prizes went to Alphonse Poitevin, in 1862 and 1867, for processes that modern historians regard as less promising in retrospect than those of some other French and English candidates $^{\text {xxxiv }}$. Also worth noting is the critic's deft parallel between English landscapes in Paris and French views of monuments in London-a harmonious chiasm applied to what was treated in France as a clear dichotomy. Indeed, Elizabeth Eastlake's photographic "republic" obeyed a distinctly "cosmopolitan" worldview" ${ }^{\mathrm{xxxv}}$.

The following section of Lady Eastlake's paper, devoted to the history of the invention, was equally non-patriotic. Not unlike that of her friend David Brewster, the narrative she wove was consistently international, or at least Franco-English, listing Niépce and Daguerre, Talbot, Niépce de St Victor and then Scott Archer (the latter elegantly internationalized in the sentence : "the Daguerre to this Niepce was a countryman of our own") before describing gun-cotton as "partly a French, partly a German discovery" and quoting a poem by Schiller in German as a measure of optimism for those discouraged by photographic disappointments ${ }^{\mathrm{xxxvi}}$. A gentle reminder of the criticisms levelled at Talbot's patents by fellow English calotypists ("photography made but slow way in England; and the first knowledge to many even of her existence came back to us from across the Border") allowed the critic to single out Edinburgh as the source of the "first earnest, professional practice of the art" in the UK, but also prompted her, once again, to spread a pacifist blanket over the early history of photography, "not so generous in character, she wrote, as that of its maturity". This tone of genteel appeasement continually reminded the reader of the new "sympathy" Eastlake exalted in her exordium, or of what she called later in the text a "new form of communication between man and man".

Her central topic, however, was a discussion of photography's merits for culture and especially for art, which makes the text's principal appeal today. To the commentary of these merits Elizabeth Eastlake brought essentially the same cosmopolitan approach, fuelled by her observations, direct or indirect, of international exhibitions, but hardly mentioning individual photographic artists - let alone nations. Her discussion of photography's semiotic and aesthetic faculties is, in fact, valued today precisely on account of its general, philosophical framework, as I have shown elsewhere ${ }^{\text {xxxvii }}$. For instance, in her lengthy discussion of landscape, she insisted on the necessary modelling of depth, a characteristic usually associated with the collodion process and therefore, in 1857, with British photography, and most if not all of her examples, explicit or implicit, were English or Scottish, but this national specialization was all but muffled in her argument. Thus it comes as something of a surprise to read, in the midst of her cosmopolitan discourse, a veiled statement of British supremacy in photography, when in her discussion of the practical conditions for successful picture-making she comes to rehearse the theory of photographic climates :

As a general rule, too, however numerous the exceptions, the cloudy day is better than the sunny one. Contrary, indeed, to all preconceived ideas, experience proves that the brighter the sky that shines above the camera the more tardy the action within it. Italy and Malta do their work slower than Paris. Under the brilliant light of a Mexican sun, half an hour is required to produce effects which in England would occupy but a minute. In the burning atmosphere of India, though photographical the year round, the process is comparatively slow and difficult to manage; while in the clear, beautiful, and, moreover, cool light of the higher Alps of Europe, it has been proved that the production of a picture requires many more 
minutes, even with the most sensitive preparations, than in the murky atmosphere of London. Upon the whole, the temperate skies of this country may be pronounced most favourable to photographic action, a fact for which the prevailing characteristic of our climate may partially account, humidity being an indispensable condition for the working state both of paper and chemicals ${ }^{\mathrm{xxxviii}}$.

Thus London's murky atmosphere was more photogenic than Arago's bright Southern suns, and, as indicated by the reference to the photographic slowness of the Alps, climatology bore directly on landscape art, indirectly explaining the British superiority in that department that the essay's discussion of photographic aesthetics suggested. Still, Eastlake's final verdict on photography's artistic potential was rather reserved (photography could help art, she famously quipped, mostly "by showing what it is not") and is remembered today, rather, for her insistence on what she called the "historic" interest of photographic details. Even though her general faith in English cultural superiority is plain from many of her writings, her eulogium of London's climate must in my opinion be read as consistent with, rather in opposition to, her general cosmopolitan view of photography as a "new form of communication", possibly elaborated in part as a response to the rise of photographic nationalisms in the 1850s, whether French, Austrian, American, or even English. In other words, by 1857 the theory of natural photographic climates remained the most polite or diplomatic expression of geo-photographic hierarchies.

In the way of conclusion, I must admit first of all that the above survey is all too partial, focusing as it does on the Franco-English debate on photography, and perhaps downplaying especially the reverberations of American cultural nationalism. Keeping in mind, however, my starting point about the apparent irrelevance of questioning photographic nationalities in the age of global visual culture, I would draw attention to the competing imperial contexts of French and British photography of the $1850 \mathrm{~s}$. Where Théophile Gautier saw a difference in artistic traditions I see a difference between political traditions and situations - one that the genteel Elizabeth Eastlake would all but suppress. What emerged in the 1850 s was, on the one hand, social and economic expansion of photographic technology, which to learned observers offered a potential promise of progress and harmony, and justified discourses on either universality or "soft" cultural difference; and, on the other, the mounting antagonism of economic and colonial empires, first and foremost British and French, secondarily American, Belgian, Austrian, Prussian, and Ottoman - those being the nationalities that were deemed worthy of notice by the 1855 jurorswhich, in the context of the Crimean War particularly, compelled the same liberal observers to acknowledge nationalities and somehow make sense of them. From this point of view the stylistic differences between British and French photographs of the Holy Land and other world sites are one expression among others of the two empires' competing appetites for strategic territory; and furthermore, this competition is not a superficial aspect but part of the very substance of the "colonizing" enterprise that has been the object of the critique of Orientalism. I think the critique of photographic colonization is quite in order - but it begins at home, in London, in Paris, even in Edinburgh, and it calls upon us to strive at more affirmatively international histories of photography. 
${ }^{\mathrm{i}}$ A version of this paper was presented at the Annual History of Photography Lecture at the University of St. Andrews on April 14, 2010. I wish to thank the organizers, especially Natalie Adamson and Annette Carruthers, for their kind support, as well as Luke Gartian, Tom Normand, and Marc Boulay, among others, for their feedback. I am also indebted, for the illustrations of this article, to Marc Boulay (University of St. Andrews Library), Violet Hamilton (Wilson Centre for Photography), Garance Chabert and Carole Troufléaux (Société Française de Photographie). I am responsible for all translations unless otherwise specified.

${ }^{\text {ii }}$ Many webpages today still cite this statement, found in Helmut Gernsheim's Creative Photography (1962) and included in Susan Sontag's anthology of quotes in On Photography (New York: Farrar, Strauss \& Giroux, 1975), p. 192. Gernsheim's statement echoed Edward Steichen's historic 1955 show The Family of Man and possibly the veteran photographer's own formulation, in a 1960 article, of photography as the "most simple, direct, universal language" of visual communication, comparable as such to the visual imagery of "cavemen", as quoted by Allan Sekula, "The Traffic in Photographs", Art Journal, Vol. 41, No. 1, Spring 1981, p. 19 and n. 24 (article, pp. 15-25). In the latter article Sekula produced a trenchant critique of the universal language myth, which he expanded into a narrative attack on the global marketing of images by Corbis in his "Between the Net and the Deep Blue Sea (Rethinking the Traffic in Photographs)", October, Vol. 102 (Autumn, 2002), pp. 3-34.

iii See, in this connection, Tom Normand's Introduction to his Scottish Photography: A History (Edinburgh : Luath Press, 2007), p. 11, where he voices a concern about the historiographic under-representation of "photography from Scotland", while insisting that his survey addresses photography from and about Scotland, without assuming something like a national Scottish photographic character.

iv Except perhaps when this subject is treated in the stylistic mode of national "schools" and "traditions", which I will discuss in the context of the 1850s (see especially below notes 27 and 28). For a recent, suggestive assessment of national "trends" in $19^{\text {th }}$-century photo-literature, see Paul Edwards, "Tendances nationales et tendances économiques dans la constitution de l'objet photolittéraire", in Jean-Pierre Montier et al., eds., Littérature et photographie, Rennes : Presses Universitaires de Rennes, 2008, pp. 37-45.

${ }^{\vee}$ See my La Naissance de l'idée de photographie, Paris: Presses Universitaires de France, 2000, chapters 1-3.

${ }^{v i}$ See François Arago, Euvres complètes, J.-A. Barral, ed, Paris : Gide \& Baudry, t. 7, 1858, pp. 516-517 ; Brunet, Naissance, p. 80.

vii On Arago's politics, see Anne McCauley, "François Arago and the Politics of the French Invention of Photography", in Daniel P. Younger, Multiple Views: Logan Grant Essays on Photography 1983-1989,

Albuquerque: University of New Mexico Press, 1991, pp. 43-70; Brunet, Naissance, p. 82-84, etc. ; more broadly, and most recently, the collection Les Arago, acteurs de leur temps (actes du colloque de Perpignan), Perpignan :

Archives départementales des Pyrénées-orientales, 2010.

viii See Sekula, "Traffic", p. 17.

ix "Drawing by the Agency of Light", unsigned review, The Edinburgh Review, No. CLIV, January, 1843, pp. 309344; partial reprint in Vicki Goldberg, Photography in Print, Writings from 1816 to the Present, New York, Simon \& Schuster, 1981. In this remarkable essay, the Scottish scientist outlined several future key themes in the cultural critique of photography, such as its affinity with "embalmment" and "mortality" (330-331).

${ }^{\mathrm{x}}$ Ibid., pp. 320-322.

xi Ibid., pp. 323, 333.

xii Ibid., pp. 343-344, Goldberg, pp. 68-69.

xiii See François Brunet, «Le point de vue français dans l'affaire Hill », Etudes photographiques, No. 16, May 2005, pp. 122-139.

${ }^{x i v}$ Quoted by Helmut Gernsheim, The Origins of Photography, London: Thames \& Hudson, 1983, p. 223.

${ }^{x v}$ André Gunthert, "L'institution du photographique, Le roman de la Société héliographique", Etudes photographiques, No. 12, Nov. 2002, pp. 56-57 (article, pp. 37-63).

${ }_{x v i}$ On 19th-century Expositions, see Paul Greenhalgh, Ephemeral Vistas. The Expositions Universelles, Great Exhibitions and World Fairs, 1851-1939, Manchester : Manchester University Press, 1988 ; Robert W. Rydell, World of Fairs: the Century-of-Progress Expositions, Chicago : University of Chicago Press, 1993 ; on the Crystal Palace Exhibition, Jeffrey A. Auerbach, Peter H. Hoffenberg, eds., Britain, the empire, and the world at the Great Exhibition of 1851, London: Ashgate, 2008 ; on the cultural politics of Second Empire Exhibitions, Patricia Mainardi, Art and Politics of the Second Empire: the Universal Expositions of 1855 and 1867, New Haven : Yale University Press, 1987.

xvii Reports by the juries on the subjects in the thirty classes into which the exhibition was divided..., London: Spicer, 1852, vol. 1, p. 244; see the comments by Gernsheim, Origins, p. 120. 
xviii Reports by the juries, p. 277; see Robert Taft, Photography and the American Scene: A Social History, 18391889 [1938], New York: Dover, 1964, pp. 68-72; Marcy J. Dinius, "Best in Show, American daguerreotypes at the Great Exhibition", Common Place, Vol. 9, No. 4, July 2009, http://www.common-place.org/vol-09/no-04/dinius/, consulted 06/04/10.

${ }^{\text {xix }}$ See Gunthert, "L'institution du photographique", p. 20 and n. 35, who notes that the 1851 Exhibition marked the first attempts at "geographical characterizations" of photography, and quotes an article, "Photography in the Palace of Glass", The Athenceum, ${ }^{\circ} 1233$, June 14, 1851, p. 632, where one reads the following remarks: "Daguerreotypes are largely displayed by the French, - as might have been expected, that country being proud of the discovery: - but the examples exhibited by the Americans surpass in general beauty of effect any which we have examined from other countries. This has been attributed to a difference in the character of solar light as modified by atmospheric conditions; we are not, however, disposed to believe that to be the case. [...] we know of no physical cause by which the superiority can be explained, - and we are quite disposed to be sufficiently honest to admit that the mode of manipulation has more to do with the result than any atmospheric influence." (quotation provided by A. Gunthert)

${ }^{\mathrm{xx}}$ See Taft, p. 69, for the quote of The Illustrated London News and a technical-professional explanation of the American success; for a longer discussion of this success, Brunet, Naissance, p. 179, and, for a general discussion of the American daguerreian "standard", ibidem, chap. 4.

${ }^{x x i}$ See André Rouillé, ed., La Photographie en France: textes et controversies, une Anthologie 1816-1871, Paris: Macula, 1989, pp. 182-296, esp. p. 218.

xxii Ernest Lacan, Esquisses photographiques, [1856], reprint Paris: Jean-Michel Place, 1979, pp. 21-22.

xxiii Exposition universelle de 1855 : Rapports du jury mixte international, Vol. 2, Paris: Imprimerie impériale, 1856, p. 569.

xxiv Ibid., p. 572

${ }^{x x v}$ Ibid., p. 573-574. In this passage the jury also expressed their regrets that Fenton's views of the Crimean war and especially the camp at Sebastopol were not displayed.

${ }^{x x v i}$ The American contribution to the 1855 exhibition consisted of a few portraits and was considered poor. In France it was widely admitted that America had neither monuments nor a taste for landscape: see Francis Wey, "Comment le soleil est devenu peintre, Histoire du daguerréotype et de la photographie", Le Musée des familles, July 20, 1853, pp. 290-291 (article, pp. 289-300).

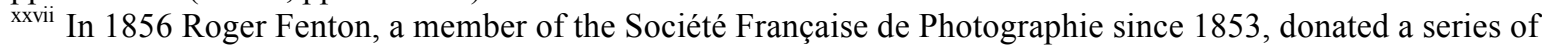
thirteen prints to the French body, which were described in the following issue of the SFP's Bulletin as including "landscapes, monuments, and groups from nature" (BSFP 1856, p. 301), and which were exhibited in 1857 along with some other Fenton prints (I thank Carole Troufléaux for this information). The fact that the "monuments" were mostly religious edifices or ruins may have contributed to the larger perception that Fenton and other English photographers did not excel in architecture.

xxviii Yeshayahu Nir, "Cultural Predispositions in Early Photography : The Case of the Holy Land", Journal of Communication, Volume 35, Issue 3 , pp. 32-50. See also the recent exhibition L'image révélée : premières photographies sur papier en Grande-Bretagne (1840-1860) (Paris: Musée d'Orsay, 2008) (Impressed by Light, British Photographs from Paper Negatives (1840-1860), presented in 2007-2008 at the Metropolitan Museum and then the Musée d'Orsay. According to the press release, "The fondness of the early British photographers for bucolic, undulating landscapes underlines the strong ties with the land at this time, of this essentially rural nation." xxix Théophile Gautier, "Exposition photographique", review in L'Artiste, déc. 1856-mars 1857 p. 193-195, reprinted in Rouillé, La Photographie en France, p. 282-285. The same text is quoted in Dominique de Font-Réaulx's essay in the catalogue to L'image révélée (see note 27 above), p. 13, with the comment that English calotypists "managed to imbue their photographic prints with a purely British character, nourished by painting and engraving".

${ }^{\mathrm{xxx}}$ On this episode and its contexts, and for references, see François Brunet, Photography and Literature, London: Reaktion Books, 2009, p. 70.

${ }^{x x x i}$ See Angelia Poon, Enacting Englishness in the Victorian Period, Colonialism and the Politics of Performance, London: Ashgate, 2008, p. 28.

xxxii [Elizabeth Eastlake], unsigned review in the Quarterly Review, vol. 101, 1857, pp. 442-468, reprinted in Beaumont Newhall, ed., Photography : Essays and Images, New York: MoMA, 1980, pp. 81-96.

xxxiii Quoted in Rouillé, La Photographie en France, p. 204.

xxxiv Ibid.

${ }^{\mathrm{xxx}}$ According to the $O E D$, the adjective cosmopolitan appears to have entered the English language in the 1840s, first in the sense of "belonging to all parts of the world", and then, especially in Emerson and Dickens, as "having the characteristics which arise from, or are suited to, a range over many different countries; free from national 
limitations or attachments." The noun cosmopolite, in the sense of "citizen of the world", was common since the 17 th century, but it enjoyed a strong revival in the first half of the 19th c., especially in opposition to "patriot".

xxxvi Eastlake, in Newhall, pp. 87-89.

xxxvii Brunet, Photography and Literature, pp. 73-75.

xxxviii Eastlake, in Newhall, p. 89. Roger Taylor, in L'image révélée, p. 21, notes that "climate conditions" were an "essential" point in the choice of processes (especially between collodion on glass and was paper) in the 1850s. 